Sains Malaysiana 48(9)(2019): 2007-2019

http://dx.doi.org/10.17576/jsm-2019-4809-22

\title{
Osteoporosis: Possible Pathways Involved and the Role of Natural Phytoestrogens in Bone Metabolism
}

(Osteoporosis: Laluan yang Mungkin Terlibat dan Peranan Fitoestrogen Semula Jadi dalam Metabolisme Tulang)

\author{
ZAR ChI THENT, SRIJIT DAS*, PASUK MAHAKKANUKRAUH \& VIRGINIA LANZOTTI
}

\begin{abstract}
The incidence of post-menopausal osteoporosis is increasing globally. In post-menopausal osteoporosis, there is deficiency in oestrogen level resulting in bone loss and fractures. Bone formation is under the control of different hormones. In the present review, we highlight few pathways such as RANKL/RANK, apoptosis and Wnt/ $\beta$-catenin signalling pathways and phytoestrogens involved in the bone metabolism. RANKL/RANK signalling is responsible for regulating the formation and activation of multinucleated osteoclasts from their precursors which is responsible for the survival of normal bone remodelling. Apoptosis regulates the development, growth and maintains the bone tissues. The Wnt pathway is an important pharmacological target for bone anabolic drugs and its future discovery. In today's world, herbal remedies are used to treat post-menopausal osteoporosis as these products contain phytoestrogens. These phytoestrogens are oestrogen like compounds which influence bone metabolism. The phytoestrogens provide better therapeutic effect in reducing the RANKL, osteoclastogenesis, inflammatory markers, and increase the osteogenic markers in the bone cells or osteoblasts. We discuss the mechanism of action of few phytoestrogens such as genistein, daidzein and equol which are beneficial for improvement of the bone health. Daidzein enhances osteoblast growth via the upregulation of BMP expression in primary osteoblast cells and it is a potential antiosteoporotic agent. Genistein also possesses antioestrogenic property by virtue of its competitive binding to the same receptors as oestradiol. Equol regulates the bone loss via hemopoiesis and inflammatory cytokine production. Thus, phytoestrogens could be efficiently used as osteoprotective agents for the treatment of individuals with post-menopausal osteoporosis.
\end{abstract}

Keywords: Fracture; oestrogen; pharmacology; post-menopausal; treatment

\section{ABSTRAK}

Kejadian osteoporosis selepas menopaus meningkat secara global. Dalam osteoporosis selepas menopaus, terdapat penurunan aras estrogen yang mengakibatkan kehilangan tulang dan patah tulang. Pembentukan tulang dikawal oleh hormon yang berbeza. Dalam ulasan kepustakaan ini, kami menyerlahkan beberapa laluan isyarat seperti RANKL/ RANK, apoptosis dan Wnt/ $\beta$-catenin serta fitoestrogens yang terlibat dalam metabolisme tulang. Isyarat RANKL/RANK bertanggungjawab mengawal pembentukan dan pengaktifan osteoklas multinukleus daripada prekursor mereka yang terlibat dalam proses pembentukan semula tulang yang normal. Apoptosis mengawal perkembangan, pertumbuhan dan penyelenggaraan tisu tulang. Laluan Wnt adalah sasaran farmakologi yang penting untuk ubat anabolik tulang dan penemuan masa depannya. Di dunia hari ini, banyak ubat-ubatan herba digunakan untuk merawat osteoporosis Osteoporosis: Possible menopaus kerana produk ini mengandungi fitoestrogen. Fitoestrogen mempunyai struktur seperti estrogen yang mempengaruhi metabolisme tulang. Fitoestrogen memberikan kesan terapeutik yang lebih baik dalam mengurangkan RANKL, osteoklastogenesis, penanda inflamasi dan meningkatkan penanda osteogenik dalam sel-sel tulang atau pun osteoblas. Kami membincangkan mekanisme tindakan beberapa fitoestrogen seperti genistein, daidzein dan equol yang bermanfaat untuk kesihatan tulang. Daidzein meningkatkan pertumbuhan osteoblas melalui peningkatan ekspresi BMP dalam sel osteoblas primer dan ia adalah agen antiosteoporotik yang berpotensi. Genistein juga mempunyai harta antioestrogenik berdasarkan daya saingnya yang kompetitif kepada reseptor yang sama seperti oestradiol. Equol mengawal kehilangan tulang melalui hemopoiesis dan penghasilan sitokin inflamasi. Oleh itu, fitoestrogen boleh digunakan sebagai agen osteoperlindungan untuk rawatan osteoporosis selepas menopaus.

Kata kunci: Estrogen; farmakologi; patah tulang; selepas menopaus; rawatan

\section{INTRODUCTION}

\section{OSTEOPOROSIS}

Osteoporosis is a common geriatric disease found in post-menopausal women, globally (Wade et al. 2014).
Osteoporosis was reported to affect approximately 28 million Americans and the costs were estimated about \$14 billion a year (Watts 1999). A recent study reported 200 million people suffering from osteopororis worldwide, with 1 in 3 women over the age of 50 years and 1 in 5 men 
predicted to suffer in their lifetime (Sözen et al. 2017). The clinical outcome and cost incurred for treatment of such disease warrants immediate attention on individuals who have high risk of developing the disease. According to research studies, the risk factors involved for osteoporotic fractures are low peak bone mass, disturbances in hormone level, consumption of drugs like glucocorticoids, smoking, decrease in physical activity, less intake of calcium and vitamin $\mathrm{D}$, ethnic race, decreased size of the body, and history of fracture (Lane 2006). Another recent study identified risk factors for osteoporosis and these include underweight, high alcohol intake, nicotine use, liver disease, inflammatory joint disorders, diabetes mellitus, hyperthyroidism and use of medications (Christian et al. 2015). It was also reported that Asians have negative attitude towards calcium and vitamin D rich foods and supplements due to lactose intolerance, lack of motivation from the family and change in taste (Chan et al. 2018). Aging also reduces bone mineral density thereby predisposing to osteoporosis (Idrus et al. 2018).

The main features of osteoporosis include bone loss, disturbance in the bone metabolism and damage to the trabecular histology of the bone, and these are associated with menopause (Jin et al. 2018). In osteoporosis, the bone becomes brittle and fracture occurs easily. Osteoporosis is considered as a silent disease but if a fracture occurs, it may give rise to chronic pain, disability, dependence on others, decrease the quality of life, and an increase in mortality cases (Lee et al. 2013). According to research reports, under-diagnosis of osteoporosis (Greenspan et al. 2012) and the unique opportunity to initiate bone modulating therapies prior to any osteoporotic fracture is usually missed in up to $84 \%$ of cases involving osteoporotic fractures (Smith et al. 2004). In many cases, osteoporosis remains undiagnosed and undertreated (Bliuc et al.2013). Osteoporosis is related to the endocrine system of the body. In post-menopausal state, there is decrease in the hormones including estrogens and bone loss is observed. Decrease in the bone density is considered to be the most important risk factor for osteoporosis (Watts 1999). The National Osteoporosis Foundation recommended bone density tests for all women aged over 65 and or even earlier (close to the time of menopause) for women who have risk factors or who were considering treatment (Watts 1999). The utmost need is to provide early diagnosis and treatment and avoid any fracture which may increase the morbidity and mortality.

\section{CHANGES IN THE BONE STRUCTURE} OCCURRING DURING OSTEOPOROSIS

Bone is a connective tissue comprising cells, fibers and extracellular matrix. As mineral deposits in the bone, it gets calcified. There is presence of mostly collagen which is a protein and provides the soft framework whereas the mineral calcium phosphate adds to the hardness and strength of the bone. The inorganic components of the matrix are mainly composed of calcium and phosphate and it is found in the form of hydroxyapatite crystals. The collagen fibers are coarse along with the hydroxyapatite crystals and it forms the basis of hardness, durability and strength of the bone.

The cells which are found in the bone include osteoclasts, osteoblasts and osteocytes. Normally, a balance exists between the action of osteoblasts and osteoclasts. It should be kept in mind that changes in osteoclast population leads to an imbalanced resorption activity, which results in increased porosity of the bone (Yahaya et al. 2018). In post-menopausal state, there is deficiency of estrogen. In osteoporosis, the actions of osteoclasts (bone removing cells) are more active than the osteoblasts (bone forming). Hence, bone is removed faster than its formation. As a result, there is much bone loss.

Trabecular and cortical bone microanatomy play a vital role in providing mechanical strength to the bone. Cortical bone is the solid outer layer around the bone and comprises dense and parallel arrangement, concentric layers, and lamellar units which are known as osteons. The cortical bone is solid and compact. The osteons are nourished and connected to each other by Haversian system and Volkmann's canal as well as canaliculi (Seeman 2006). The periosteum is located on its outer surface while on the inner surface, it is lined by the endosteum. On the other hand, trabecular or spongy bone exhibits a typical network of lamellar bone plates and rods. The structure of trabecular or spongy bone resembles a 'honeycomb structure'. In osteoporosis, both cortical bone and the trabecular bone loss is a common feature. The bones become brittle and fracture occurs easily.

\section{GROWTH AND DEVELOPMENT OF LONG BONE}

At the fourth week of embryonic development, the cartilage is formed. The skeleton which is primarily made up of cartilage, possess no minerals. As the foetus grows, the cartilage is gradually replaced with osteoblasts and osteoclasts and then later on, ossification begins. Osteoblasts serve as the main important event in the bone formation during normal physiological process of bone turnover. Osteoblasts stimulate bone growth and facilitate bone resorption by regulating the osteoclasts which produces two different cytokines i.e. the receptor activator of NF-kB ligand (RANK-L) and osteoprotegrin (OPG), with the former promoting and the latter blocking the osteoclast activity, respectively (Marriott 2004). Osteoclasts are highly specialized multinucleated cells that resorb bone or invade mineralized tissue in a regulated manner. Osteoclasts dissolves the inorganic and the protein components of the bone matrix (Teitelbaum 2007).

There are two types of ossifications which include intramembranous and endochondral ossification. Both chondrocytes and osteoblasts originate from the common osteochondro progenitor cells. Bone growth occurs due to two major ossification processes i.e. endochondral ossification and intramembranous ossification, and these involve chondrocytes and osteoblasts. Formation of 
chondroclast/osteoclast is influenced by receptor activator of nuclear factor-kappa B ligand (RANKL), which is secreted from the osteoblasts and bone marrow stromal cells. In intramembranous ossification, the mesenchymal tissue is directly converted into bone tissue. The process occurs primarily in the flat bones at the eighth week of intrauterine life and completed at the age of two years. In endochondral ossification, mesenchymal cells differentiate into chondrocytes which subsequently becomes hypertrophic and die by apoptosis. With the gradual death of cartilage cells, there is replacement by the differentiated osteoblasts.

Bone growth can also be classified into interstitial and appositional growth. In interstitial growth, the epiphyseal plate (cartilage) is replaced by bone and results in lengthening whereas appositional growth results in increase in the width (diameter) of a bone. Appositional growth occurs when osteoblasts located beneath periosteum secrete bone matrix on the bone surface and osteoclasts located on the endosteal surface remove the bone.

\section{HORMONAL REGULATION OF BONE GROWTH}

In the younger age period, the growth of bones is widely controlled by growth hormones such as thyroid hormones and sex hormones and these include testosterone and oestrogen. At puberty, the closure of the epiphyseal plates and cessation of the longitudinal growth of the bone is due to the sex hormones. Hence, hormonal therapy can influence bone growth.

In the light of hormonal influence towards bone growth or bone loss, there is much concern regarding the exposure to environmental oestrogenic chemicals towards bone loss. The osterogenic chemicals negatively affected a number of human health disorders i.e. testicular carcinoma, precocious puberty, decrease sperm count, hypospadias, and cryptorchidism including bone metabolism (Carlsen et al. 1993).

Bone homeostasis is due to a dynamic balance between bone remodeling and bone resorption by osteoblasts and osteoclasts, respectively (Seeman \& Delmas 2006). In bone remodeling, there is synthesis of organic matrix by osteoblasts, and bone resorption by osteoclasts. This equilibrium is controlled by different physical parameters (i.e. mechanical stimulations) and numerous polypeptides (includes hormones, cytokines). Any disturbance between these effectors leads to bone abnormalities which is characterized by the decrease (osteoporosis) or increase (osteopetrosis) in the bone mass.

Osteoblasts and osteoclasts comprise of metabolic cells. Estrogen, progesterone and androgen act as important regulators in the bone metabolism. Sex hormones are responsible for maintaining bone function and mineral homeostasis during reproduction. Deficiency in certain sex steroids has an effect on the bone health and its metabolism (Van Pottelbergh et al. 2004). It is noteworthy to mention that RANKL is important for the formation of osteoclasts. Increased bone resorption in sex hormones deficiency is also related to the RANKL expression (Saika et al. 2001). There is substantial scientific evidence to show that sex steroids regulate the RANKL-OPG axis in the bone microenvironment, and the relative contribution of immune cell-derived versus mesenchymal cell-derived RANKL was poorly defined (Streicher et al. 2017).

We highlight the effect of phytoestrogen on bone health and explain how the changes in hormonal action by environmental chemicals causes disruption to the bone metabolism. There are several research reports, which are still controversial. There are also unexplained queries related to the factors influencing the bone metabolism or bone health. In general, oestrogen is considered as a potent bone resorption inhibitor and if there is any disturbance in its hormonal level, it causes bone loss or osteoporosis in any individual.

\section{DIFFERENT PATHWAYS WHICH ACT ON THE BONE METABOLISM RANKL/RANK SIGNALLING PATHWAY}

The receptor activator of nuclear factor- $\kappa \mathrm{B}$ ligand (RANKL) plays an important role in the regulation of the bone resorption (Thomas \& Dong 2006). RANKL/RANK signalling is responsible for regulating the formation and activation of multinucleated osteoclasts from their precursors which is responsible for the survival of normal bone remodelling. RANKL acts along with osteoprotegrin (OPG) to prevent excessive bone resorption. OPG binds to the RANKL and prevents the binding from its own receptor, RANK. Previous research studies showed that RANKL/RANK signalling is also essential for lymph node formation and mammary gland lactational hyperplasia. OPG and RANKL are considered as members of a ligandreceptor system that controls osteoclast differentiation and bone resorption (Yasuda et al. 1998). RANKL not only activates mature osteoclasts but also mediates the process of osteoclastogenesis in the presence of M-CSF (Kong et al. 1999). Soluble and membranous form of RANKL is expressed by preosteoblastic cells but their specific receptor RANK is located on the osteoclast progenitor cells (Lacey et al. 1998). This interaction is crucial absence of RANKL which is unable to produce osteoclasts. In this system, OPG, a decoy receptor, produced by osteoblasts prevents RANKL from binding to its own receptor. It also inhibits the osteoclasts formation and downregulates the RANKL signalling (Tsuda et al. 1997). Although the presence of OPG inhibits the process of osteoclastogenesis, excess OPG results in severe osteopetrosis and decreased formation of mature osteoclasts (Simonet et al. 1997). In contrast, absence of OPG results in osteoporotic state (Mizuno et al. 1998). OPG improves the bone cells by inhibiting differentiation, suppressing activation, and inducing apoptosis of mature osteoclasts (Theill et al. 2002). Hence, bone remodelling is mainly under the control of RANKL/OPG.

RANKL and OPG are found in different tumour cells. Soluble RANKL was produced by the prostate cancer cells in humans after being injected to SCID mice 
(Zhang et al. 2001). The tumour cells which expressed RANKL were relatively higher in all bone metastases. Immunohistochemical findings showed positive RANKL staining in primary benign and malignant tumours of the bone and the bone metastases (Good et al. 2002). These research findings proved that increased RANKL expression was found in the bone tumour cells. As bone remodelling is the result of activity of osteoblast and osteoclast, pathological bone loss is due to a disturbance in the mechanism. Since its discovery, the RANKL/OPG system in osteoclast showed the pivotal role played by RANKL/ OPG system between osteoblasts and osteoclasts (Theill et al. 2002). The ratio of RANKL and its natural inhibitors $\mathrm{OPG}$, is increased in severe conditions where there is bone loss. OPG stops the binding between RANKL and RANK, thereby playing an important role as the major inhibitor of osteoporosis. The RANKL/OPG ratio is the main mechanism which is involved in the pathogenesis of glucocorticoidinduced osteoporosis (Chiodini et al. 1998).

Thus, the facts related to the compensatory role of OPG On RANKL are well justified. The positive expression of RANKL in osteoclasts is due to an internalization of this ligand following binding to its specific receptor RANK, found on the cell membrane. The presence of inflammatory macrophage polykaryon which is deficient in RANK expression explains the heterogeneity in response. OPG has a highly basic heparin binding domain which makes interactions with heparin and heparan sulfates possible and this provides the scientific evidence of a new control mechanism for biological activity of the OPG. Proteoglycans which are expressed on the osteoclast membrane account for the internalization of OPG alone or are associated with RANKL into the osteoclasts. The serum levels of RANKL are increased in all patients with bone diseases (Terpos 2003). Interestingly, the RANKL/OPG ratio also correlates with markers of bone resorption and bone disease.

BPA suppresses RANK expression of osteoclasts in mRNART-PCR. The exposure with BPA for $24 \mathrm{~h}$ consistently downregulated one of the RANKL-induced transcription factors, NFATc1, and other signalling factors, such as MAPK, ERK, and AKT (Hwang et al. 2013). The dose of BPA (0.5, 2.5 and $12.5 \mu \mathrm{M}$ ) was observed on bone marrow cells isolated from the femur and tibia bones of 5-week-old BKW mice and RAW264.7 mouse monocyte/macrophage cell line (Hwang et al. 2013; Martin \& Sims 2005). A study conducted on mammary glands of the animals exposed to BPA, showed significant Wnt-mRNA and RANKL expression in BPA $(6 \mu \mathrm{g} / \mathrm{kg}-\mathrm{bw} / \mathrm{d})$ exposed animals. Consequently, the animals showed an increase in the progesterone expression (Martin \& Sims 2005). However, the direct effect of BPA on RANKL expression in bone metabolism still remains unknown.

Oestrogen (E2) downregulates osteoclast formation by decreasing interleukins production (IL-1,-6 and TNF) and cytokines that augment RANKL production from osteoblasts. E2 also decreases the 'response of mature osteoclasts to RANKL by deactivating the Jun N-terminal kinase (JNK).
JNK, a mitogen activated protein kinase, is activated during binding of RANKL of its own receptor RANK' (Ayyanan et al. 2011). 'E2 suppressed the ability of RANKL to induce the activation of JNK1 by decreasing the levels of c-Fos and c-Jun' (Srivastava et al. 2001). Hence, E2 checks osteoclastogenesis by decreasing the responsiveness of OC precursors to the osteoclastogenic cytokine RANKL. BPA mimics the oestrogenic effects but it interacts differently on the ligand binding domain of oestrogen receptors. As a result, it reverses the effect of oestrogen by increasing the RANKL expression and stimulates the osteoclastogenesis. BPA inhibits bone mineralization and bone mass formation by blocking both osteoblasts and osteoclasts differentiation (Hwang et al. 2013).

\section{APOPTOSIS PATHWAY}

Bone is a mineralized and dynamic tissue, affected by different kinds of stimuli during its remodelling process (Sims \& Walsh 2012; Stains \& Civitelli 2005). The stimuli from endocrine, paracrine, and autocrine directly affect the cell to cell communications through gap junctions (Stains \& Civitelli 2005), or through the hemichannels (Watkins et al. 2011). The gap junctions and hemichannels contribute to the survival and death of the cell, i.e. apoptosis. Cell apoptosis are related to different physiological and pathological conditions. Apoptosis regulates the development, growth and maintains the bone tissues (Giner et al. 2013), but it is a cause of worry as the bone tissue is inactive at cellular level (Hughes \& Boyce 1998). In physiological conditions like aging, the risk of apoptosis is quite high and this results in the decrease in the formation of osteoblasts and bone (Almeida 2012).

'The key adhesion molecules needed for bone cell development and apoptosis is the caspase which plays an important role in osteoblast apoptosis' (Miura et al. 2004). 'Apoptosis in osteoblast is influenced by extracellular signal-regulated kinase (ERK), mitogenactivated protein kinases (MAPK), JAK2 and Fas' (Liu et al. 2013, 2008). Factors like oxidized lipids which inhibit osteoblast differentiation through reactive oxygen species (ROS)-independent mechanisms and induce apoptosis in osteoblasts. Osteoblasts apoptosis is an important factor in stimulating bone loss compared to the osteocytes and osteoclasts.

\section{Wnt/B-CATENIN SIGNALLING PATHWAY}

The Wnt/ $\beta$-catenin signalling pathway is a well-known pathway in normal organogenesis occurring during fetal development. It has an important role in the cellular processes including cell survival, cell proliferation, and cell fate specification (Bakre et al. 2007). The involvement of $\mathrm{Wnt} / \beta$ catenin signalling pathway in bone metabolism is an area of interest to researchers. Wnts, a family of 19 secreted glycoproteins, binds to complexes receptor including lowdensity lipoprotein receptor-related protein (LRP)-5/6 and frizzled proteins. Subsequently, the intracellular cascade stabilizes $\beta$-catenin, leading to its translocation into the 
nucleus and accentuates the gene expression. Wnt pathway is a potential pharmacological target for bone anabolic drug discovery.

Wnt, rich in cysteine, and according to description it 'forms a family of 19 highly conserved secreted signalling molecules which plays an important role in the osteoblastogenesis/bone formation' (Pandur et al. 2002). The number of Wnts involved in the bone formation is yet to be outlined. 'Wnt1, Wnt3a activates the canonical Wnt signalling pathway in formation of Wnt frizzled proteins and LRP5 or LRP6 receptors' (Tamai et al. 2000). 'The noncanonical Wnt5a class binds to frizzled proteins, activates heterotrimeric $\mathrm{G}$ proteins and increases intracellular calcium via protein kinase C-dependent mechanisms or induces cytoskeleton formation' (Veeman et al. 2003).

Known members of the LDL receptor family serve cell signalling functions in various tissues and cell types (Kanazawa et al. 2004). Human low-density lipoprotein (LDL) receptor-related proteins (LRP5 and 6) are homologous. Wnts are lipid-modified and it acts on the LRPs and promote the signalling. LRP5/6 functions along with $\mathrm{Fz}$ to stimulate the catenin pathway in response to different Wnt proteins (Brown et al. 1998). Wnt pathway, regulates the expression of certain transcription factors, such as Runx2, Osterix and dlx5 (Bennett et al. 2005). In addition, Wnt signalling up-regulates Runx 2 transcription in both osteoprogenitor cells and embryonic mesenchymal cells while promoting the entry of mesenchymal cells into the osteogenic lineage for both endochondral and intramembranous bone formation (Gaur et al. 2005). On the other hand, Wnt3a controls osteoclastogenesis through Runx2, the down-regulation of RANKL expression and induction (Gaur et al. 2005). These reciprocal changes in RANKL and OPG expression mediate the effect of Wnt signalling on osteoclast differentiation in vivo. A strong link between Wnt and osteoblastogenesis through interaction with the heterodimer Smad/Runx2 was also suggested. Cbfa1 (Core binding factor a1)/Runx2 (runt related transcriptional factor 2) determines the osteoblast lineage from multi-potent mesenchymal cells, induces osteoblastic differentiation at the early stage and inhibits it at the late stage (Banerjee et al. 1997; Komori et al. 1997). Moreover, Runx 2 was reported to induce alkaline phosphatase (ALP) activity, expression of bone matrix protein genes and mineralization in in vitro osteoblastic cell line (Ducy et al. 1997). The Wnt cascade activates Src/ERK, AKT proteins and promotes anti-apoptotic effect. The Wnt induced Runx-2 transcription regulates the expression of RANKL and OPG. The Ca2+ mediated non-canonical Wnt pathway promotes osteoblast differentiation. Studies performed on transgenic mice showed that osteoblast lineage was targeted to increase Wnt signalling, and it resulted in increased osteoprotegerin (OPG) production and decreased osteoclast formation (Glass et al. 2005; Thirunavukkarasu et al. 2000).

The $\mathrm{Wnt} / \beta$ catenin signalling pathway regulates osteoclast formation by suppressing the RANKL expression and/or up-regulating the OPG expression. OPG is a decoy receptor produced by osteoblasts that binds to the RANKL and inhibits osteoclastogenesis (Bakre et al. 2007). An important concern is whether the $\mathrm{Wnt} / \beta$-catenin signalling is modulated by ROS. The oxidative stress condition alters the link of $\beta$-catenin with its nuclear partners, which include LEF, forkhead box transcription factors (FoxOs), hypoxia-inducible factor (HIF-1), and p53 (Taylor et al. 2011). Depending on the duration of the oxidative stress, cellular process such as cell survival or cell death varies. Recently, molecular studies demonstrated that Wnt/ $\beta$ catenin signalling alters the cell survival program and promotes cell death (Kawamoto et al. 2012). Wnt is a major mediator of osteoblastogenesis and osteoclastogenesis and these were observed both in vitro and in-vivo.

\section{ROLE OF PHYTOESTROGENS}

Phytoestrogens (PEs) are naturally occurring plant products. They mimic or modulate endogenous hormones like oestradiol by exerting the oestrogenic or/and antioestrogenic effects (Setchell et al. 2001). They are present in different fruits, vegetables, and whole grains. They belong to the Leguminosae family (Dixon 2004; Michel et al.2013), and they are found in soy/soy protein, red clover, kudzu, hops, licorice, rhubarb, yam, and chasteberry (Hajirahimkhan et al. 2013). 'PEs are divided into three (3) main classes: Phytoestrogens (genistein, daidzein, formonetin, biochanin $\mathrm{A}$, and equol), lignans (enterolactone, enterodiol, pinoresinol, lariciresinol, secoisolariciresinol, matairesinol), and coumestans (e.g. coumestrol)' (Cornwell et al. 2004; Ibarreta et al. 2001). Phytoestrogens are also found in soybeans, lignans in flaxseed, and coumestans in clover, alfalfa and soybean sprouts. It was mentioned that phytoestrogens are the main active compounds in soy/soy protein which possess multiple therapeutic effects (Chen et al. 2003).

Depending on the geographical location of different nations and their cultures, the intake of phytoestrogens varies and Malaysia is an ideal example (Figure 1). In the Asian population, approximately $20-50 \mathrm{mg}$ of phytoestrogens are consumed daily (Fritz et al. 2013; Mense et al. 2008). There are epidemiological studies which suggested the recommended dose of phytoestrogens in reducing the risk of cardiovascular diseases in postmenopausal women (Moreira et al. 2014). However, the mechanism of action of phytoestrogens towards bone loss still debatable. It is noteworthy to mention that PE serves as an oestrogen antagonist by blocking the potent endogenous oestrogen to bind its own receptor. Several literature provide conflicting reports on the mechanism of action of phytoestrogens (Paterni et al. 2014; Rietjens et al. 2013; Younes 2011). The different research findings on the effect of phytoestrogens, depends on their dose, class, presence or absence of endogenous oestrogens and oestrogen receptors (ER $\alpha$ and ERß) (Benassayag \& PerrotApplanat 2002).

Although there are several studies which outlined the positive effect of herbs or compounds against bone 


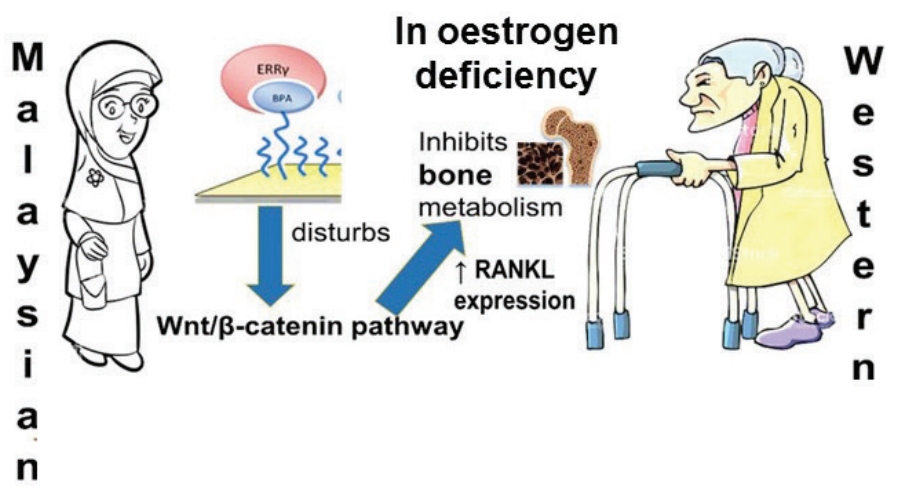

FIGURE 1. Schematic diagram to show that the tendency to have osteoporosis is more in the Western population compared to Malaysian population. This is attributed to more consumption of local dietary food rich in phytoestrogens in Malaysia

loss, the role of phytoestrogens in regulating the disease was not summarised, to date. In the present review, we focused mainly on the mechanism of phytoestrogens such as genistein, daidzein and equol in improving the bone health. The effect of these three bioactive compounds on bone health were further discussed in detail.

\section{DAIDZEIN}

Daidzein (4', 7-dihydroxyisoflavone, $\mathrm{C}_{15} \mathrm{H}_{10} \mathrm{O}_{4}$ ) is natural phytoestrogen which belongs to the family of diphenolic compounds and has structural similarity to natural and synthetic oestrogen (Figure 2) (Lampe 2003). Daidzein in the bound form 'daidzin', becomes inactive. It is found in leguminous plants such as soy and mung bean. It is the second most abundant phytoestrogen found in soy, next to genistein. Asians were reported to consume 15-50 mg of daidzein/day, compared to the Western individuals who consumed approximately 1-2 mg (Froyen et al. 2009). Interestingly, in countries like Japan where soy intake is quite high, there is approximately $85 \%$ lower rate of health ailments as comparted to that in the West. It is commonly used as a bioactive compound in traditional Chinese medicine Gegen (Wang et al. 2003). According to published literature, it has been used effectively in the treatment of fever, acute dysentery, diarrhoea, diabetic conditions, cardiac problems and liver injury (Wong et al. 2011). Recent research reports show that following knee surgery, daidzein was also even able to reduce intraarticular adhesion around the knee (Liu et al. 2017).

Daidzein exhibits a chemical structure which is very similar to oestrogen. It either replaces or interferes with the oestrogen and the oestrogen-receptor (ER) complex. Therefore, daidzein attenuates the oestrogen related diseases which includes breast carcinoma, osteoporosis and different cardiovascular diseases (Vitale et al. 2013). In addition, diadzein has positive effects on non-oestrogen related diseases which include properties such as antiinflammatory, anticancerous and has a role in oxidative stress related diseases and protection of skin and the nerves. Diadzein regulates the immune system (Masilamani et

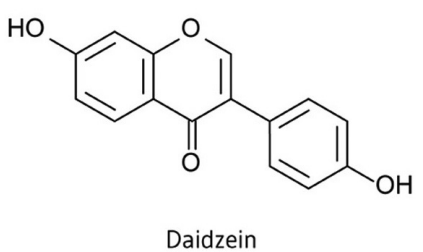

FIGURE 2. Chemical structure of Daidzein (Lampe JW 2003)

al. 2012), scavenging oxygen free radicals and inhibiting VSMCs proliferation. A recent research study showed that daidzein showed an increase in body mass, increase in trabecular bone mass and decreased the bone turnover rate in severe andropause animal models (Ajdžanovic et al. 2018).

Few metabolites of daidzein exhibit a similar pattern. Equol $\left(\mathrm{C}_{15} \mathrm{H}_{14} \mathrm{O}_{3}\right)$ is a metabolite of daidzein which is commonly present in the soy/soy protein (Törmälä et al. 2008). Soy phytoestrogens are capable to biotransform into potent oestrogenic metabolite, equol, enhancing its actions. Equol has greater affinity for oestrogen receptors, exhibits unique anti-androgenic properties, and has potent antioxidant actions (Kang et al.2007). Equol is metabolized from daidzein in the human body with the help of intestinal flora. This compound increases the bone mineral density, affects the vasomotor symptoms, decreases the level of low density lipoprotein and also improves the endothelial dysfunction (Cassidy \& Albertazzi 2006; Sirtori 2001).

Daidzein is a potential antiosteoporotic agent which possesses both osteogenic and anticancer activities (Adjakly et al. 2013; Chen et al. 2015). Daidzein was reported to enhance osteoblast growth via the upregulation of BMP expression in primary osteoblast cells (Jia et al. 2003). Daidzein promoted cell differentiation and mineralization in mouse osteoblast-like MC3T3-E1 cells (Ge et al. 2006). The effect of Daidzein on osteoblasts were mediated through the oestrogen related beta (ER-beta) pathway (De Wilde et al. 2004). However, the detail mechanism concerned with antiosteoporosis properties of Daidzein and the effected pathway is still being debated by researchers. 
It was observed that Daidzein increased the cells viability, ALP activity, osteocalcin synthesis and BMP-2 expression in primary osteoblast cells (Jia et al. 2003). According to earlier research findings, Daidzein improved the ostegenic genes expression such as ALP, Smad1, Runx2, Osx, Col I, in human bone marrow-derived mesenchymal stem cells (HBMSCs) (Strong et al. 2014). Daidzein stimulated the osteoblast differentiation and mineralisation in MC3T3-E1 cells as well as in OCT1 cells (Ge et al. 2006). The effect of Daidzein on osteoblast differentiation was mediated by the expression of BMP-2 (Jia et al. 2003). Moreover, Dz inhibited osteoclast differentiation by increasing ER-alpha expression (Babu et al. 2012; Palacios et al. 2005).

\section{GENISTEIN}

Genistein (40, 5, 7-trihydroxyisoflavone, $\left.\mathrm{C}_{15} \mathrm{H}_{10} \mathrm{O}_{5}\right)$ is natural flavonoid of Leguminoseae plants, and it is a phytoestrogen which exhibits dual agonist and antagonist oestrogenic properties (Figure 3) (Danciu et al. 2012). Genistein was used for the prevention and treatment of chronic diseases. Genistein exhibits vasodilator, antithrombotic and anti-atherosclerotic effects through various mechanisms (Lee 2006; Messina et al. 2006; WilliamsonHughes et al. 2006). Genistein bears structural similarities with the chemopreventive agent tamoxifen, and (Marrian \& Haslewood 1932) equol, a dietary isoflavone formed by gastrointestinal flora (Kwon 2014). In addition to the oestrogenic activities, genistein also contributes to the anti-oestrogenic activities by competitively binding to the same receptors as oestradiol (Kwon 2014). Genistein was effectively used in the treatment of atherosclerosis. Genistein administered in the dose of $0.1 \mu \mathrm{mol} / \mathrm{L}$ improved the endothelial nitric oxidase synthase (eNOS) uncoupling related to sirtuin-1 pathway in ox-LDL-induced human umbilical vein endothelial cells (HUVECs). It was reported that eNOS uncoupling was a major factor which caused endothelial dysfunction in atherosclerosis (Zhang et al. 2016). Moreover, genistein was reported to decrease the superoxide production and NOX4 expression, increase the ratio of $\mathrm{BH} 4 / \mathrm{BH}$, the expression of GTP cyclohydrolase 1 (GCH1) and dihydrofolate reductase (DHFR) (Babu et al. 2012).

Phytoestrogens mainly found in soybean was shown to improve bone loss in individuals in inhabitants of Eastern part of the globe and its effect on bone metabolism was solely due to the action of the soybean phytoestrogens which included diadzein, genistein and equol. Both, EDC and phytoestrogens bind to the oestrogen receptors.

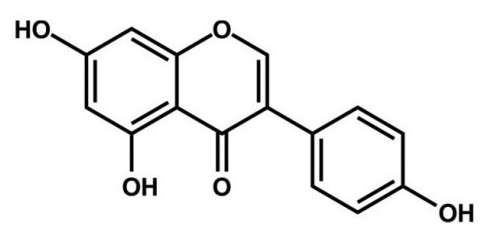

FIGURE 3. Chemical structure of Genistein (Danciu et al. 2012)
However, it is most likely to differ with regard to types of oestrogen receptors. BPA acts more on the non-classical oestrogen receptor $\gamma$, while phytoestrogens trigger the classical oestrogen ( $\alpha$ and $\beta$ ) pathway. This difference in binding is probably due to the antagonising effect on bone health. However, less is known on the fact whether the phytoestrogens can protect against BPA induced bone loss.

\section{EQUOL}

Equol, a metabolite of diadzein, is an important isoflavone of soybean (Figure 4). It is considered to be more biologically active comparted to other isoflavone aglycone (Setchell \& Clerici 2010; Yuan et al. 2007). Researchers observed the metabolism of isoflavones and biological actions of equol in detail (Setchell et al. 2002). The oestrogenic effects of equol were documented following discovery of the first oestrogen receptor (ER). Equol binds to ERs and induces transcription (Chang et al. 1975). Equol, a chiral molecule, is found as enantiomers R-equol and S-equol. It was shown that S-equol, has relatively high affinity for ERs compared to R-equol (Saitoh et al. 2004). Equol was reported to inhibit bone loss in ovariectomised mice and rats (Fujioka et al. 2004; Kolios et al. 2009; Ohtomo et al. 2008). In an in vitro study, equol inhibited the osteoclastogenesis induced by oestradiol (Ohtomo et al. 2008). Epidemiologic studies showed that high equol producers often reduce the risk of breast cancer compared to the low producers (Adlercreutz et al. 2002). Postmenopausal high equol producers had decreased bone loss compared to the low producers (Vatanparast $\&$ Chilibeck 2007). A recent research study showed that equol was able to improve the bone and cardiovascular parameters in middle-aged Japanese females (Yoshikata et al. 2018).

It is pertinent to mention that $\mathrm{S}$-equol inhibited decrease in the bone mineral density of postmenopausal women without causing any major side effects (Tousen et al. 2011). Equol was shown to prevent bone loss in the ovariectomised mice (Fujioka et al. 2004). Equol is very similar to selective ER modulators while preventing bone loss without oestrogenic activity.

It was observed that equol acted on bone loss and changes in immune system-related genes caused by deficiency of oestrogen. Equol regulates bone loss via hemopoiesis and inflammatory cytokine production. It promotes the process of proliferation and differentiation of primary cultured osteoblasts by increasing the osteoblast differentiation markers, ALP and osteocalcin and blocking the ER antagonist. It was suggested that equol has an action like ER agonist on the osteoblasts. Interestingly, the metabolic ability of equol is different among different races (Jou et al. 2008; Setchell et al. 2002). Hence, the controversial research findings of soy isoflavones in the management of osteoporosis or bone loss may be due to differences in the production and metabolism of equol in different individuals. 


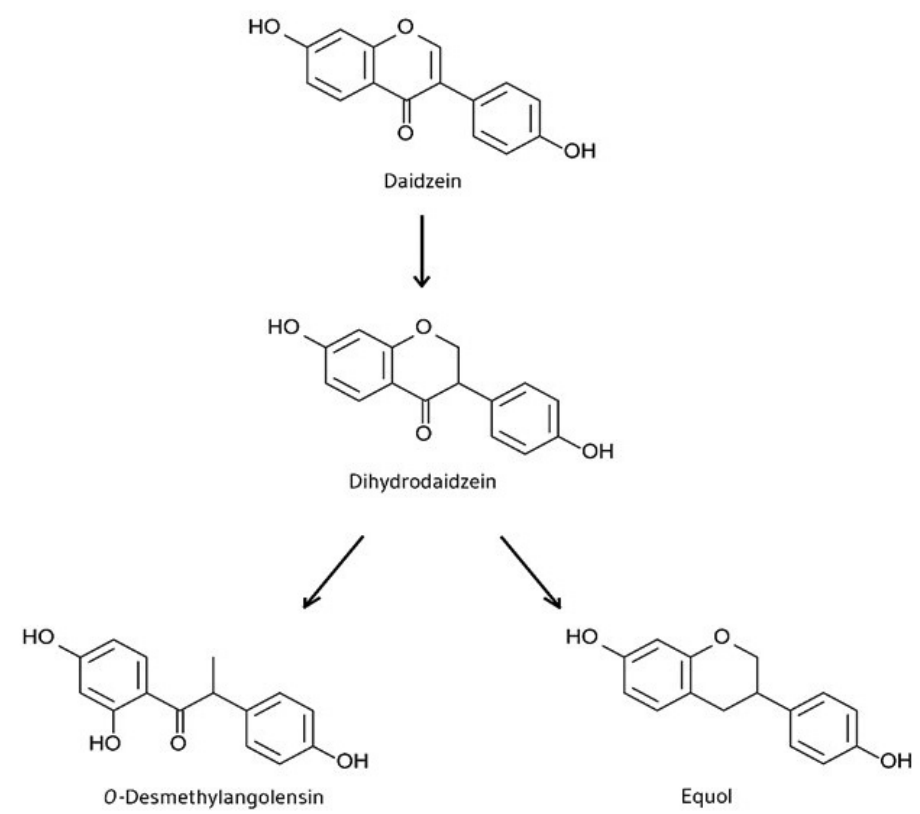

FIGURE 4. Chemical structure of Equol, a metabolite of Diadzein (Setchelo \& Clerici 2010)

The majority of studies reported beneficial effect of phytoestrogens on bone (Figure 5) but there are few studies which reported less effects. A past study reported that daidzein and equol slightly reduced but reduced the bone loss was certainly not significant (Tousen et al. 2014). Another research study stated that genistein did not significantly reduce the serum osteoclacin compared to commercial oestrogenic compound against postmenopausal osteoporosis (Miao et al. 2012). There are also reports of lack of favorable effects of genistein on the mineralization of bone and mechanical properties as seen in estrogen deficient animals (Sliwiński et al. 2009). Interestingly, a recent research study also showed that synergestic phytochemicals failed to protect bone loss in ovariectomised rats (Ambati et al. 2018).

TREATMENT OPTIONS IN POST-MENOPAUSAL OSTEOPOROSIS

One of the mainstays of treatment in post-menopausal women is replacement of the bone loss. This has to be done in order to avoid the vertebral and non-vertebral (hip) fractures. Hormone replacement therapy is advised. Oestrogen replacement is the treatment of choice. Other hormones include progestin, progesterone, testosterone in different composition. Drugs such as alendronate, raloxifene, risedronate, 1-34 fragment of parathyroid hormone, and nasal calcitonin are advised for effective treatment (Delmas 2002). Adequate level of Calcium and Vitamin D has to be maintained. Treatment with estrogens checks the osteoclastic resorption and helps to conserve the bone mass (Al-Anazi et al. 2011). Anabolic hormones i.e. progesterone, stimulates osteoblastic activity of bone and the use of the combination of estrogen and progesterone decreases the risk of uterine cancers besides treatment of osteoporosis (Al-Anazi et al.2011). Androgen replacement also increases the bone mass in the affected individual. All allopathic drugs are known to cause several side-effects. Hence, there is need to look for natural products which may be helpful for treating postmenopausal osteoporosis. One such potent natural product is phytooestrogen.

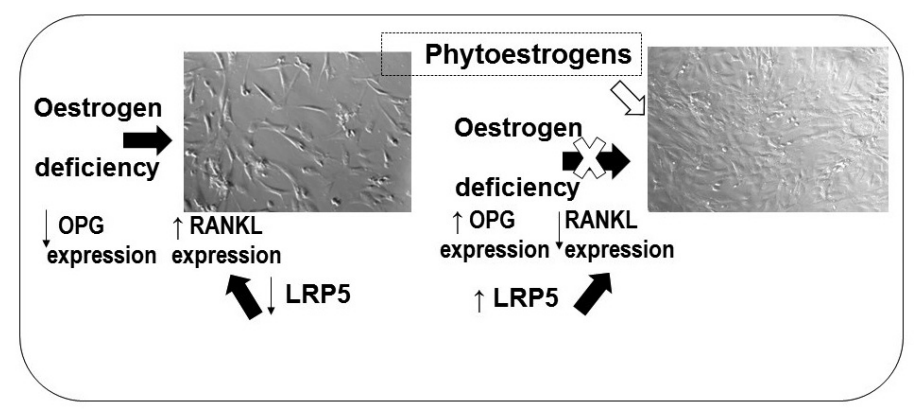

FIGURE 5. Figure showing the effect of phytoestrogen on $\mathrm{Wnt} / \beta$ catenin pathway in osteoblasts 
The phytoestrogens are polyphenol compounds derived from plants and their structure resemble the steroid hormone 17-beta-estradiol. The source of these phytoestrogens may be from supplements or even soy based products. Soy isoflavones have similar structurally and functional to that of 17-beta-estradiol and it acts on osteoblasts and osteoclasts via genomic and non-genomic pathways to produce beneficial effects on bone metabolism, bone turnover markers, and mechanical strength of bones in the postmenopausal state (Atmaca et al. 2008). Isoflavones binds to estrogen receptors on the target cell surface and this may be helpful in the treatment of osteoporosis in the post-menopausal state.

\section{CONCLUSION}

The knowledge of different pathways leading to bone loss and bone metabolism is necessary for effective treatment of osteoporosis and its complications. Conventional drugs used for treatment for osteoporosis have several side effects including cancer. This opens the door to look for synthetic and natural products. Natural products have gained popularity because of easy availability, less cost, fewer side effects and patient compliance. Phytoestrogens have similar structure to estrogen and they can be used to treat estrogen deficiency state. Use of phytoestrogen may also be beneficial on uterus and other reproductive organs. It has to be considered that not all humans are capable of metabolising daidzein to equol. Hence, the role of phytoestrogens may also vary but in the majority of cases, metabolism occurs and phytoestrogens have a positive role in maintaining bone health. In the present review, we aimed to highlight the pathways and the phytoestrogens involved in bone metabolism. Further clinical trials are advised in future to ascertain the efficacy and long term benefits of natural products like phytoestrogens.

\section{ACKNOWLEDGEMENTS}

No funding was received for the study. All authors have no conflict of interest to declare.

\section{REFERENCES}

Adlercreutz, H. 2002. Phyto-oestrogens and cancer. Lancet. Oncol. 3(6): 364-373.

Adjakly, M., Ngollo, M., Boiteux, J.P., Bignon, Y.J., Guy, L. \& Bernard-Gallon, D. 2013. Genistein and daidzein: Different molecular effects on prostate cancer. Anticancer Res. 33(1): 39-44.

Ajdžanovic, V.Z., Trifunovic, S., Miljic, D., Šošic-Jurjevic, B., Filipovic, B., Miler, M., Ristic, N., Manojlovic-Stojanoski, M. \& Miloševic, V. 2018. Somatopause, weaknesses of the therapeutic approaches and the cautious optimism based on experimental ageing studies with soy isoflavones. EXCLI J. 17: 279-301.

Al-Anazi, A.F., Quresh, V.F., Javaid, K. \& Qureshi, S. 2011. Preventive effects of phytoestrogens against postmenopausal osteoporosis as compared to the available therapeutic choices: An overview. J. Nat. Sci. Biol. Med. 2(2): 154-163.
Almeida, M., Iyer, S., Martin-Millan, M., Bartell, S.M., Han, L., Ambrogini, E., Onal, M., Xiong, J., Weinstein, R.S., Jilka, R.L., O’Brien, C.A. \& Manolagas, S.C. 2013. Estrogen receptor- $\alpha$ signaling in osteoblast progenitors stimulates cortical bone accrual. J. Clin. Invest. 123(1): 394-404.

Ambati, S., Miller, C.N., Bass, E.F., Hohos, N.M., Hartzell, D.L., Kelso, E.W., Trunnell, E.R., Yang, J.Y., Della-Fera, M.A., Baile, C.A. \& Rayalam, S. 2018. Synergistic phytochemicals fail to protect against ovariectomy induced bone loss in rats. J. Med. Food 21(10): 1044-1052.

Atmaca, A., Kleerekoper, M., Bayraktar, M. \& Kucuk, O. 2008. Soy isoflavones in the management of postmenopausal osteoporosis. Menopause 15(4): 748-757.

Ayyanan, A., Laribi, O., Schuepbach-Mallepell, S., Schrick, C., Gutierrez, M., Tanos, T., Lefebvre, G., Rougemont, J., Yalcin-Ozuysal, O. \& Brisken, C. 2011. Perinatal exposure to bisphenol a increases adult mammary gland progesterone response and cell number. Mol. Endocrinol. 25(11): 19151923.

Babu, P.V.A., Si, H., Fu, Z., Zhen, W. \& Liu, D. 2012. Genistein prevents hyperglycemia induced monocyte adhesion to human aortic endothelial cells through preservation of the cAMP signaling pathway and ameliorates vascular inflammation in obese diabetic mice. J. Nutr. 142(4): 724-730.

Bakre, M.M., Hoi, A., Mong, J.C., Koh, Y.Y., Wong, K.Y. \& Stanto, L.W. 2007. Generation of multipotential mesendodermal progenitors from mouse embryonic stem cells via sustained Wnt pathway activation. J. Biol. Chem. 282(43): 31703-31712.

Banerjee, C., Mccabe, L.R., Choi, J., Hiebert, S.W., Stein, J.L., Stein, G.S. \& Lian, J.B. 1997. Runt homology domain proteins in osteoblast differentiation: AML3/CBFA1 is a major component of a bone-specific complex. J. Cell Biochem. 66(1): 1-8.

Benassayag, C., Ferre, F. \& Perrot-Applanat, M. 2002. Phytoestrogens as modulators of steroidaction in target cells. J. Chromatogr. B Analyt. Technol. Biomed. Life Sci. 777(1-2): 233-248.

Bennett, C.N., Longo, K.A., Wright, W.S., Suva, L.J., Lane, T.F., Hankenson, K.D. \& MacDougald, O.A. 2005. Regulation of osteoblastogenesis and bone mass by Wnt10b. Proc. Natl. Acad. Sci. USA 102(9): 3324-3329.

Bliuc, D., Nguyen, N.D., Nguyen, T.V., Eisman, J.A. \& Center, J.R. 2013. Compound risk of high mortality following osteoporotic fracture and refracture in elderly women and men. J. Bone Miner. Res. 28(11): 2317-2324.

Brown, S.D., Twells, R.C.J., Hey, P.J., Cox, R.D., Levy, E.R., Soderman, A.R., Metzker, M.L., Caskey, C.T., Todd, J.A. \& Hess, J.F. 1998. Isolation and characterization of LRP6, a novel member of the low density lipoprotein receptor gene family. Biochem. Biophys. Res. Commun. 248(3): 879-888.

Carlsen, E., Giwercman, A. \& Skakkebaek, N.E. 1993. Declining sperm counts and increasing incidence of testicular cancer and other gonadal disorders: Is there a connection? Ir. Med. J. 86(3): 85-96.

Cassidy, A., Albertazzi, P., Lise Nielsen, I., Hall, W., Williamson, G., Tetens, I., Atkins, S., Cross, H., Manios, Y., Wolk, A., Steiner, C. \& Branca, F. 2006. Critical review of health effects of soyabean phytooestrogens in post-menopausal women. Proc. Nutr. Soc. 65(1): 76-92.

Chan, C.Y., Norazlina, M., Ima-Nirwana, S. \& Kok, Y.C. 2018. Attitude of Asians to calcium and vitamin D rich foods and supplements: A systematic review. Sains Malaysiana 47(8): 1801-1810. 
Chang, H.H., Robinson, A.R. \& Common, R.H. 1975. Excretion of radioactive diadzein and equol as monosulfates and disulfates in the urine of the laying hen. Can. J. Biochem. 53(2): 223-230.

Chen, Y.M., Ho, S.C., Lam, S.S., Ho, S.S. \& Woo, J.L. 2003. Soy isoflavones have a favorable effect on bone loss in chinese postmenopausal women with lower bone mass: A doubleblind, randomized, controlled trial. J. Clin. Endocrinol. Metab. 88(10): 4740-4747.

Chen, Y., Cass, S.L., Kutt, S.K., Yee, E.M.H., Chan, D.S.H., Gardner, C.R., Vittorio, O., Pasquier, E., Black, D.S. \& Kumar, N. 2015. Bioorganic \& medicinal chemistry letters synthesis, biological evaluation and structure - Activity relationship studies of isoflavene based Mannich bases with potent anticancer activity. Bioorganic \& Medicinal Chemistry Letters 25(22): 5377-5383.

Chiodini, I., Carnevale, V., Torlontano, M., Fusilli, S., Guglielmi, G., Pileri, M., Modoni, S., Di Giorgio, A., Liuzzi, A., Minisola, S., Cammisa, M., Trischitta, V. \& Scillitani, A. 1998. Alterations of bone turnover and bone mass at different skeletal sites due to pure glucocorticoid excess: Study in eumenorrheic patients with Cushing's Syndrome. J. Clin. Endocrinol. Metab. 83: 1863-1867.

Christian, S., Wallaschofski, H., Nauck, M., Völzke, H., Schober, H.C. \& Hannemann, A. 2015. Fracture risk and risk factors for osteoporosis: Results from two representative populationbased studies in North East Germany (Study of Health in Pomerania: SHIP-2 and SHIP-Trend). Dtsch. Arztebl. Int. 112 (21-22): 365-371.

Cornwell, T., Cohick, W. \& Raski, I. 2004. Dietary phytoestrogens and health. Phytochemistry 65(8): 995-1016.

Danciu, C., Soica, C., Csanyi, E., Ambrus, R., Feflea, S., Peev, C. \& Dehelean, C. 2012. Changes in the anti-inflammatory activity of soy isoflavonoid genistein versus genistein incorporated in two types of cyclodextrin derivatives. Chem. Cent. J. 6(1): 58.

Delmas, P.D. 2002. Treatment of postmenopausal osteoporosis. Lancet 359(9322): 2018-2026.

De Wilde, A., Lieberherr, M., Colin, C. \& Pointillart, A. 2004. A low dose of daidzein acts as an ER $\beta$-selective agonist in trabecular osteoblasts of young female piglets. J. Cell Physiol. 200(2): 253-262.

Dixon, R.A. 2004. Phytoestrogens. Annu. Rev. Plant Biol. 55: 225-261.

Ducy, P., Zhang, R., Geoffroy, V., Ridall, A.L. \& Karsenty, G. 1997. Osf2/Cbfa1: A transcriptional activator of osteoblast differentiation. Cell 89(5): 747-754.

Fritz, H., Seely, D., Flower, G., Skidmore, B., Fernandes, R., Vadeboncoeur, S., Kennedy, D., Cooley, K., Wong, R., Sagar, S., Sabri, E. \& Fergusson, D. 2013. Soy, red clover, and isoflavones and breast cancer: A systematic review. PLoS ONE 8: e81968.

Froyen, E.B., Reeves, J.L.R., Mitchell, A.E. \& Steinberg, F.M. 2009. Regulation of phase II enzymes by genistein and daidzein in male and female Swiss Webster mice. J. Med. Food 12(6): 1227-1237.

Fujioka, M., Uehara, M., Wu, J., Adlercreutz, H., Suzuki, K., Kanazawa, K., Takeda, K., Yamada, K. \& Ishimi, Y. 2004. Equol, a metabolite of daidzein, inhibits bone loss in ovariectomized mice. J. Nutr. 134(10): 2623-2627.

Gaur, T., Lengner, C.J., Hovhannisyan, H., Bhat, R.A., Bodine, P.V., Komm, B.S., Javed, A., van Wijnen, A.J., Stein, J.L., Stein, G.S. \& Lian, J.B. 2005. Canonical WNT signaling promotes osteogenesis by directly stimulating Runx 2 gene expression. J. Biol. Chem. 280(39): 33132-33140.

Ge, Y., Chen, D., Xie, L. \& Zhang, R. 2006. Enhancing effect of daidzein on the differentiation and mineralization in mouse osteoblast-like MC3T3-E1 cells. Yakugaku Zasshi 126(8): 651-656.

Giner, M., Montoya, M.J., Vázquez, M.A., Miranda, C. \& PérezCano, R. 2013. Differences in osteogenic and apoptotic genes between osteoporotic and osteoarthritic patients. $B M C$ Musculoskelet Disord 25: 41.

Glass, D.A., Bialek, P., Ahn, J.D., Starbuck, M., Patel, M.S., Clevers, H., Taketo, M.M., Long, F., McMahon, A.P., Lang, R.A. \& Karsenty, G. 2005. Canonical Wnt signaling in differentiated osteoblasts controls osteoclast differentiation. Dev. Cell 8(5): 751-764.

Greenspan, S.L., Perera, S., Nace, D., Zukowski, K.S., Ferchak, M.A., Lee, C.J., Nayak, S. \& Resnick, N.M. 2012. FRAX or fiction: Determining optimal screening strategies for treatment of osteoporosis in residents in long-term care facilities. J. Am. Geriatr. Soc. 60(4): 684-690.

Good, C.R., O'Keefe, R.J., Puzas, J.E., Schwarz, E.M. \& Rosier, R.N. 2002. Immunohistochemistry study of receptor activator of nuclear kappa-B ligand (RANK-L) in human osteolytic bone tumors. J. Surg. Oncol. 79(3): 174-179.

Hajirahimkhan, A., Dietz, B.M. \& Bolton, J.L. 2013. Botanical modulation of menopausal symptoms: Mechanisms of action? Planta. Med. 79(7): 538-553.

Hughes, D.E. \& Boyce, B.F. 1998. Estrogen, transforming growth factor-beta, and the regulation of bone metabolism in health and disease. The Endocrinologist 8: 55-61.

Hwang, J.K., Min, K.H., Choi, K.H., Hwang, Y.C., Jeong, I.K., Ahn, K.J., Chung, H.Y. \& Chang, J.S. 2013. Bisphenol A reduces differentiation and stimulates apoptosis of osteoclasts and osteoblasts. Life Sci. 93(9-11): 367-372.

Ibarreta, D., Daxenberger, A. \& Meyer, H.H. 2001. Possible health impact of phytoestrogens and xenoestrogens in food. APMIS 109(3): 161-184.

Idrus, R.B.H., Sainik, N.Q.A.V., Ansari, A.S., Zulfarina, M.S., Razali, R.A., Nordin, A., Saim, A.B. \& Naina-Mohamed, I. 2018. Ficus carica and bone health: A systematic review. Sains Malaysiana 47(11): 2741-2755.

Jia, T.L., Wang, H.Z., Xie, L.P., Wang, X.Y. \& Zhang, R.Q. 2003. Daidzein enhances osteoblast growth that may be mediated by increased bone morphogenetic protein (BMP) production. Biochem. Pharmacol. 65(5): 709-715.

Jin, D., Wu, X., Yu, H., Jiang, L., Zhou, P., Yao, X., Meng, J., Wang, L., Zhang, M. \& Zhang, Y. 2018. Systematic analysis of IncRNAs, mRNAs, circRNAs and miRNAs in patients with postmenopausal osteoporosis. Am. J. Transl. Res. 10(5): 1498-1510.

Jou, H.J., Wu, S.C., Chang, F.W., Ling, P.Y., Chu, K.S. \& Wu, W.H. 2008. Effect of intestinal production of equol on menopausal symptoms in women treated with soy isoflavones. Int. J. Gynecol. Obstet. 102(1): 44-49.

Kanazawa, A., Tsukada, S., Sekine, A., Tsunoda, T., Takahashi, A., Kashiwagi, A., Tanaka, Y., Babazono, T., Matsuda, M., Kaku, K., Iwamoto, Y., Kawamori, R., Kikkawa, R., Nakamura, Y. \& Maeda, S. 2004. Association of the gene encoding wingless-type mammary tumor virus integrationsite family member 5B (WNT5B) with type 2 diabetes. $A m$. J. Hum. Genet. 75(5): 832-843.

Kang, J.S., Yoon, Y.D., Han, M.H., Han, S.B., Lee, K., Park, S.K. \& Kim, H.M. 2007. Equol inhibits nitric oxide production and 
inducible nitric oxide synthase gene expression through down regulating the activation of Akt. Int. Immunopharmacol. 7(4): 491-499.

Kawamoto, E.M., Gleichmann, M., Yshii, L.M., Lima Lde, S., Mattson, M.P. \& Scavone, C. 2012. Effect of activation of canonical Wnt signaling by the Wnt-3a protein on the susceptibility of PC12 cells to oxidative and apoptotic insults. Braz. J. Med. Biol. Res. 45(1): 58-67.

Kolios, L., Sehmisch, S., Daub, F., Rack, T., Tezval, M., Stuermer, K.M. \& Stuermer, E.K. 2009. Equol but not genistein improves early metaphyseal fracture healing in osteoporotic rats. Planta. Med. 75: 459-465.

Komori, T., Yagi, H., Nomura, S., Yamaguchi, A., Sasaki, K., Deguchi, K., Shimizu, Y., Bronson, R.T., Gao, Y.H., Inada, M., Sato, M., Okamoto, R., Kitamura, Y., Yoshiki, S. \& Kishimoto, T. 1997. Targeted disruption of Cbfa1 results in a complete lack of bone formation owing to maturational arrest of osteoblasts. Cell 89(5): 755-764.

Kong, Y.Y., Boyle, W.J. \& Penninger, J.M. 1999. Osteoprotegerin ligand: A common link between osteoclastogenesis, lymph node formation and lymphocyte development. Immun. Cell. Biol .77(2): 188-193.

Kwon, Y. 2014. Effect of soy isoflavones on the growth of human breast tumors: Findings from preclinical studies. Food Sci. Nutr. 2(6): 613-622.

Lacey, D.L., Timms, E., Tan, H.L., Kelley, M.J., Dunstan, C.R., Burgess, T., Elliott, R., Colombero, A., Elliott, G., Scully, S., Hsu, H., Sullivan, J., Hawkins, N., Davy, E., Capparelli, C., Eli, A., Qian, Y.X., Kaufman, S., Sarosi, I., Shalhoub, V., Senaldi, G., Guo, J., Delaney, J. \& Boyle, W.J. 1998. Osteoprotegerin ligand is a cytokine that regulates osteoclast differentiation and activation. Cell 93(2): 165-176.

Lampe, J.W. 2003. Isoflavonoid and lignan phytoestrogens as dietary biomarkers. J. Nutr. 133(Suppl 3): 956S-964S.

Lane, N.E. 2006. Epidemiology, etiology, and diagnosis of osteoporosis. Am. J. Obstet. Gynecol. 1949: S3-S11.

Lee, S.R., Ha, Y.C., Kang, H., Park, Y.G., Nam, K.W. \& Kim, S.R. 2013. Morbidity and mortality in Jeju residents over 50 -years of age with hip fracture with mean 6-year followup: A prospective cohort study. J. Korean Med. Sci. 28(7): 1089-1094.

Liu, D., Genetos, D.C., Shao, Y., Geist, D.J., Li, J., Ke, H.Z., Turner, C.H. \& Duncan, R.L. 2008. Activation of extracellular-signal regulated kinase (ERK1/2) by fluid shear is $\mathrm{Ca}(2+)$ and ATP-dependent in MC3T3-E1 osteoblasts. Bone 42(4): 644-652.

Liu, C.G., Luo, Q.X., Ling, T.Y., Mo, Y.Y., Cheng, Z.L., Huang, S.G. \& Mo, H. 2013. Effect of erigeron breviscapus on the expression of OPG/RANKL/RANK in osteoblasts and pre osteoclasts in vitro. Zhongguo Zhong Xi Yi Jie He Za Zhi 33: 1658-1664.

Liu, X., Jia, H. \& Xia, H. 2017. Reduction of intra-articular adhesion by topical application of daidzein following knee surgery in rabbits. Afr. J. Tradit. Complement. Altern. Med. 14: 265-271.

Marrian, G.F. \& Haslewood, G.A. 1932. Equol, a new inactive phenol isolated from the ketohydroxyoestrin fraction of mares' urine. Biochem. J. 26: 1227-1232.

Marriott, I. 2004. Osteoblast responses to bacterial pathogens: A previously unappreciated role for bone-forming cells in host defense and disease progression. Immunol. Res. 30(3): 291-308.
Masilamani, M., Wei, J. \& Sampson, H.A. 2012. Regulation of the immune response by soybean isoflavones. Immunol. Res. 54: 95-110.

Martin, T.J. \& Sims, N.A. 2005. Osteoclast-derived activity in the coupling of bone formation to resorption. Trends Mol. Med. 11(2): 76-81.

Mense, S.M., Hei, T.K., Ganju, R.K. \& Bhat, H.K. 2008. Phytoestrogens and breast cancer prevention: Possible mechanisms of action. Environ. Health Perspect. 116(4): 426-433.

Messina, M., McCaskill-Stevens, W. \& Lampe, J.W. 2006. Addressing the soy and breast cancer relationship: Review, commentary, and workshop proceedings. J. Natl. Cancer Inst. 98(18): 1275-1284.

Miao, Q., Li, J.G., Miao, S., Hu, N., Zhang, J. \& Zhang, S. 2012. The bone-protective effect of genistein in the animal model of bilateral ovariectomy: Roles of phytoestrogens and PTH/ PTHR1 against post-menopausal osteoporosis. Int. J. Mol. Sci. 13: 56-70.

Michel, T., Halabalaki. \& Skaltsounis, A.L. 2013. New concepts, experimental approaches, and dereplication strategies for the discovery of novel phytoestrogens from natural sources. Planta Med. 79(7): 514-532.

Miura, M., Chen, X.D., Allen, M.R., Bi, Y., Gronthos, S., Seo, B.M., Lakhani, S., Flavell, R.A., Feng, X.H., Robey, P.G., Young, M. \& Shi, S. 2004. A crucial role of caspase-3 in osteogenic differentiation of bone marrow stromal stem cells. J. Clin. Invest. 114: 1704-1713.

Mizuno, A., Amizuka, N., Irie, K., Murakami, A., Fujise, N., Kanno, T., Sato, Y., Nakagawa, N., Yasuda, H., Mochizuki, S., Gomibuchi, T., Yano, K., Shima, N., Washida, N., Tsuda, E., Morinaga, T., Higashio, K. \& Ozawa, H. 1998. Severe osteoporosis in mice lacking osteoclastogenesis inhibitory factor/osteoprotegerin. Biochem. Biophys. Res. Commun. 247(3): 610-615.

Moreira, A.C., Silva, A.M., Santos, M.S. \& Sardão, V.A. 2014. Phytoestrogens as alternative hormone replacement therapy in menopause: What is real, what is unknown. J. Steroid Biochem. Mol. Biol. 143: 61-71.

Ohtomo, T., Uehara, M., Peñalvo, J.L., Adlercreutz, H., Katsumata, S.I., Suzuki, K., Takeda, K., Masuyama, R. \& Ishimi, Y. 2008. Comparative activities of daidzein metabolites, equol and O-desmethylangolensin, on bone mineral density and lipid metabolism in ovariectomized mice and in osteoclast cell cultures. Eur. J. Nutr. 47(5): 273-279.

Palacios, V.G., Robinson, L.J., Borysenko, C.W., Lehmann, T., Kalla, S.E. \& Blair, H.C. 2005. Negative regulation of RANKL-induced osteoclastic differentiation in RAW264.7 cells by estrogen and phytoestrogens. J. Biol. Chem. 280(14): 13720-13727.

Pandur, P., Maurus, D. \& Kuhl, M. 2002. Increasingly complex: New players enter the Wnt signaling network. BioEssays 24(10): 881-884.

Paterni, I., Granchi, C., Katzenellenbogen, J.A. \& Minutolo, F. 2014. Estrogen receptors alpha $(E R \alpha)$ and beta $(E R \beta)$ : Subtype-selective ligands and clinical potential. Steroids 90: $13-29$.

Rietjen, I.M., Sotoca, A.M., Vervoort, J. \& Louisse, J. 2013. Mechanisms underlying the dualistic mode of action of major soy isoflavones in relation to cell proliferation and cancer risks. Mol. Nutr. Food Res. 57(1): 100-113.

Saika, M., Inoue, D., Kido, S. \& Matsumoto, T. 2001. 17 betaestradiol stimulates expression of osteoprotegerin by a 
mouse stromal cell line, ST-2, via estrogen receptor-alpha. Endocrinology 142(6): 2205-2212.

Saitoh, S., Sato, T., Harada, H. \& Matsuda, T. 2004. Biotransformation of soy isoflavone glycosides in laying hens: Intestinal absorption and preferential accumulation into egg yolk of equol, a more estrogenic metabolite of daidzein. Biochim. Biophys. Acta Gen. Subj. 1674(2): 122-130.

Seeman, E. \& Delmas, P.D. 2006. Bone quality-The material and structural basis of bone strength and fragility. N. Engl. J. Med. 354(21): 2250-2261.

Setchell, K.D.R., Brown, N.M. \& Lydeking-Olsen, E. 2002. The clinical importance of the metabolite equol-a clue to the effectiveness of soy and its isoflavones. J. Nutr. 132(12): 3577-3584.

Setchell, K.D. 2001. Soy isoflavones-Benefits and risks from nature's selective estrogen receptor modulators (SERMs). J. Am. Coll. Nutr. 20(5): 354S-362S.

Setchell, K.R. \& Clerici, C. 2010. Equol: History, chemistry, and formation. J. Nutr. 3: 1355-1362.

Sims, N.A. \& Walsh, N.C. 2012. Intercellular cross-talk among bone cells: New factors and pathways. Curr. Osteoporos. Rep. 10(2): 109-117.

Simonet, W.S., Lacey, D.L., Dunstan, C.R., Kelley, M., Chang, M.S., Lüthy, R., Nguyen, H.Q., Wooden, S., Bennett, L., Boone, T., Shimamoto, G., DeRose, M., Elliott, R., Colombero, A., Tan, H.L., Trail, G., Sullivan, J., Davy, E., Bucay, N., Renshaw-Gegg L, Hughes, T.M., Hill, D., Pattison, W., Campbell, P., Sander, S., Van, G., Tarpley, J., Derby, P., Lee, R. \& Boyle, W.J. 1997. Osteoprotegerin: A novel secreted protein involved in the regulation of bone density. Cell 89(2): 309-319.

Sliwiński, L., Folwarczna, J., Nowińska, B., Cegieła, U., Pytlik, M., Kaczmarczyk-Sedlak, I., Trzeciak, H. \& Trzeciak, H.I. 2009. A comparative study of the effects of genistein, estradiol and raloxifene on the murine skeletal system. Acta Biochim. Pol. 56(2): 261-270.

Smith, M.G., Dunkow, P.\& Lang, D.M. 2004. Treatment of osteoporosis: Missed opportunities in the Hospital fracture clinic. Ann. R. Coll. Surg. of Engl. 86(5): 344-346.

Sözen, T., Özışık, L. \& Başaran, N.Ç. 2017. An overview and management of osteoporosis. Eur. J. Rheumatol. 4(1): 46-56.

Srivastava, S., Toraldo, G., Weitzmann, M.N., Cenci, S., Ross, F.P. \& Pacifici, R. 2001. Estrogen decreases osteoclast formation by down-regulating receptor activator of NF-kappa B ligand (RANKL)-induced JNK activation. J. Biol. Chem. 276(12): 8836-8840.

Stains, J.P. \& Civitelli, R. 2005. Cell-cell interactions in regulating osteogenesis and osteoblast function. Birth Defects Res. C. Embryo Today 75(1): 72-80.

Streicher, C., Heyny, A., Andrukhova, O., Haigl, B., Slavic, S., Schüler, C., Kollmann, K., Kantner, I., Sexl, V., Kleiter, M., Hofbauer, L.C., Kostenuik, P.J. \& Erben, R.G. 2017. Estrogen regulates bone turnover by targeting RANKL expression in bone lining cells. Sci. Rep. 7(1): 6460.

Strong, A.L., Jiang, Q., Zhang, Q., Zheng, S., Boue, S.M., Elliott, S., Burow, M.E., Bunnell, B.A. \& Wang, G. 2014. Design, synthesis, and osteogenic activity of daidzein analogs on human mesenchymal stem cells. ACS Med. Chem. Lett. 5(2): 143-148.

Tamai, K., Semenov, M., Kato, Y., Spokony, R., Liu, C., Katsuyama, Y., Hess, F., Saint-Jeannet, J.P. \& He, X. 2000. LDL receptor-related proteins in Wnt signal transduction. Nature 407: 530-535.
Taylor, J.A., Richter, C.A., Ruhlen, R.L. \& vom Saal, F.S. 2011. Estrogenic environmental chemicals and drugs: Mechanisms for effects on the developing male urogenital system. $J$. Steroid Biochem. Mol. Biol. 127(1-2): 83-95.

Teitelbaum, S.L. 2007. Osteoclasts: What do they do and how do they do it? Am. J. Pathol. 170(2): 427-435.

Terpos, E. 2003. Soluble receptor activator of nuclear factor B ligand-osteoprotegerin ratio predicts survival in multiple myeloma: Proposal for a novel prognostic index. Blood 102(3): 1064-1069.

Theill, L.E., Boyle, W.J. \& Penninger, J.M. 2002. RANK-L and RANK: T cells, bone loss, and mammalian evolution. Annu. Rev. Immunol. 20: 795-823.

Thirunavukkarasu, K., Halladay, D.L., Miles, R.R., Yang, X., Galvin, R.J., Chandrasekhar, S., Martin, T.J. \& Onyia, J.E. 2000. The osteoblast-specific transcription factor Cbfal contributes to the expression of osteoprotegerin, a potent inhibitor of osteoclast differentiation and function. J. Biol. Chem. 275(33): 25163-25172.

Thomas, P. \& Dong, J. 2006. Binding and activation of the seventransmembrane estrogen receptor GPR30 by environmental estrogens: A potential novel mechanism of endocrine disruption. J. Steroid Biochem. Mol. Biol. 102(1-5): 175-179.

Törmälä, R., Appt, S., Clarkson, T.B., Mueck, A.O., Seeger, H., Mikkola, T.S. \& Ylikorkala, O. 2008. Impact of soy supplementation on sex steroids and vascular inflammation markers in postmenopausal women using tibolone: Role of equol production capability. Climacteric 11(5): 409-415.

Tousen, Y., Wolber, F.M., Chua, W.H., Tadaishi, M., Ishimi, Y. \& Kruger, M.C. 2014. Effects of daidzein and kiwifruit on bone mineral density and equol production in ovariectomised rats. Int. J. Food Sci. Nutr. 65(3): 360-367.

Tousen, Y., Ezaki, J., Fujii, Y., Ueno, T., Nishimuta, M. \& Ishimi, Y. 2011. Natural S-equol decreases bone resorption in postmenopausal, non-equol-producing Japanese women: A pilot randomized, placebo-controlled trial. Menopause 18(5): 563-574.

Tsuda, E., Goto, M., Mochizuki, S.I., Yano, K., Kobayashi, F., Morinaga, T. \& Higashio, K. 1997. Isolation of a novel cytokine from human fibroblasts that specifically inhibits osteoclastogenesis. Biochem. Biophys. Res. Commun. 234(1): 137-142.

Vatanparast, H. \& Chilibeck, P.D. 2007. Does the effect of soy phytoestrogens on bone in postmenopausal women depend on the equol-producing phenotype? Nutr. Rev. 65(6): 294-299.

Veeman, M.T., Axelrod, J.D. \& Moon, R.T. 2003. A second canon: Functions and mechanisms of $\beta$-catenin-independent Wnt signaling. Developmental Cell 5(3): 367-377.

Van Pottelbergh, I., Goemaere, S., Zmierczak, H. \& Kaufman, J.M. 2004. Perturbed sex steroid status in men with idiopathic osteoporosis and their sons. J. Clin. Endocrinol. Metab. 89(10): 4949-4953.

Vitale, D.C., Piazza, C., Melilli, B., Drago, F. \& Salomone, S. 2013. Isoflavones: Estrogenic activity, biological effect and bioavailability. Eur J Drug Metab Pharmacokinet 38(1): 15-25.

Wade, S.W., Strader, C., Fitzpatrick, L.A., Anthony, M.S. \& O'Malley, C.D. 2014. Estimating prevalence of osteoporosis: Examples from industrialized countries. Arch. Osteoporos. 9: 182.

Wang, X., Wu, J., Chiba, H., Umegaki, K., Yamada, K. \& Ishimi, Y. 2003. Puerariae radix prevents bone loss in ovariectomized mice. J. Bone Miner. Metab. 21(5): 268-275. 
Watkins, A.J., Lucas, E.S., Wilkins, A., Cagampang, F.R. \& Fleming, T.P. 2011. Maternal periconceptional and gestational low protein diet affects mouse offspring growth, cardiovascular and adipose phenotype at 1 year of age. PLoS ONE 6: e28745.

Watts, N.B. 1999. Postmenopausal osteoporosis. Obstet. Gynecol. Surv. 54(8): 532-538.

Williamson-Hughes, P.S., Flickinger, B.D., Messina, M.J. \& Empie, M.W. 2006. Isoflavone supplements containing predominantly genistein reduce hot flash symptoms: A critical review of published studies. Menopause 13(5): 831-839.

Wong, K.H., Li, G.Q., Li, K.M., Razmovski-Naumovski, V. \& Chan, K. 2011. Kudzu root: Traditional uses and potential medicinal benefits in diabetes and cardiovascular diseases. J. Ethnopharmacol. 134(3): 584-607.

Yahaya, M.F., Zainodin, A., Pupathy, R., Min, E.O.H., Bakar, N.H.A., Zamri, N.A., Ismail, H. \& Mohd Ramli, E.S. 2018. The effect of palm tocotrienol on surface osteoblast and osteoclast in excess glucocorticoid osteoporotic rat model. Sains Malaysiana 47(11): 2731-2739.

Yasuda, H., Shima, N., Nakagawa, N., Yamaguchi, K., Kinosaki, M., Mochizuki, S., Tomoyasu, A., Yano, K., Goto, M., Murakami, A., Tsuda, E., Morinaga, T., Higashio, K., Udagawa, N., Takahashi, N. \& Suda, T. 1998. Osteoclast differentiation factor is a ligand for osteoprotegerin/ osteoclastogenesis inhibitory factor and is identical to TRANCE/RANKL. Proc. Natl. Acad. Sci. USA 95(7): 3597-3602.

Yuan, J.P., Wang, J.H. \& Liu, X. 2007. Metabolism of dietary soy isoflavones to equol by human intestinal microflora Implications for health. Mol. Nutr. Food Res. 51(7): 765-781.

Yoshikata, R., Myint, K.Z.Y. \& Ohta, H. 2018. Effects of equol supplement on bone and cardiovascular parameters in middleaged Japanese women: A prospective observational study. $J$. Altern. Complement. Med. 24(7): 701-708.

Younes, M.H.N. 2011. Estrogen receptor. Pathol. Lab. Med. 135: 63-66.

Zhang, H.P., Zhao, J.H., Yu, H.X. \& Guo, D.X. 2016. Genistein ameliorated endothelial nitric oxidase synthase uncoupling by stimulating sirtuin-1 pathway in ox-LDL- injured HUVECs. Environ. Toxicol. Pharmacol. 42: 118-124.
Zhang, J., Dai, J., Qi, Y., Lin, D.L., Smith, P., Strayhorn, C., Mizokami, A., Fu, Z., Westman, J. \& Keller, E.T. 2001. Osteoprotegerin inhibits prostate cancer-induced osteoclastogenesis and prevents prostate tumor growth in the bone. J. Clin. Invest. 107(10): 1235-1244.

\section{Zar Chi Thent}

Anatomy Discipline, Basic Medical Science Cluster Faculty of Medicine, Sungai Buloh Campus

Universiti Teknologi MARA

47000 UiTM Sungai Buloh, Selangor Darul Ehsan Malaysia

\section{Srijit Das*}

Department of Anatomy

Faculty of Medicine

Universiti Kebangsaan Malaysia Medical Centre Jalan Yaacob Latif, Bandar Tun Razak 56000 Cheras, Kuala Lumpur, Federal Territory Malaysia

Pasuk Mahakkanukrauh

Forensic Osteology Research and Training Centre

Excellence Center of Osteology Research and

Training Center \& Department of Anatomy

Faculty of Medicine, Chiang Mai University

Chiang Mai 50200

Thailand

\section{Virginia Lanzotti}

Dipartimento di Agraria

University of Naples Federico II

Via Università 100

80055 Portici, Naples

Italy

*Corresponding author; email: drsrijit@gmail.com

Received: 17 May 2019

Accepted: 5 July 2019 